\title{
Caracterización de los morteros de relleno usados en diferentes túneles españoles
}

\section{Characterization of backfill mortars used in different tunnels in Spain}

\author{
S. Cavalaro(*), A. Aguado(*)
}

Recepción/Received: 20-VI-11

Aceptación/Accepted: 7-V-12

Publicado online/Online publishing: 30-VII-12

\section{RESUMEN}

El objetivo principal del presente estudio es llevar a cabo la comparación de las dosificaciones de mortero de relleno empleadas en algunos de los grandes túneles españoles para rellenar el hueco anular dejado entre el terreno y el extradós de las dovelas. Inicialmente se hace una nueva propuesta experimental usando la composición y los materiales correspondientes a 6 dosificaciones usadas en 4 túneles. Los resultados obtenidos indican diferencias significativas en cuanto a la densidad, a la consistencia y a las propiedades reológicas. De acuerdo con las estimaciones realizadas, ello se traduce en diferencias de hasta un $67 \%$ en la potencia requerida del sistema de bombas de la tuneladora para inyectar el material. Por otro lado, se refleja una correlación entre el contenido de finos de la mezcla y las propiedades reológicas. Esa correlación puede servir para controlar y modificar dichas propiedades de manera fácil y rápida a pie de obra.

Palabras clave: mortero; tensión umbral; viscosidad; tuneladora; túnel.

\section{SUMMARY}

The main objective of this paper is to compare typical backfill mortars used in Spanish tunnels to fill the annular void left between the lining and the ground by the TBM. Initially, a new experimental program is outlined using material corresponding to 6 mixes from 4 tunnels. The results obtained indicate a considerable difference in the density and in the rheological properties of the mixes tested. According to the estimations performed, this leads to a difference of up to $67 \%$ on the potency required from the pumps to inject the material. Furthermore, a correlation between the fine content and the rheological properties of the mix was observed. This correlation may be a practical tool to control and modify the performance of the mortars directly in the worksite.

Keywords: mortar; yield stress; viscosity; tunnel boring machine; tunnel.

(*) Universidad Politécnica de Cataluña (Barcelona, España).

Persona de contacto/Corresponding author: sergio.pialarissi@upc.edu 


\section{INTRODUCCIÓN}

Durante la construcción de túneles con tuneladora (TBM), la máquina produce una sobre-excavación del terreno la cual se rellena mediante la inyección de morteros a presión. La inyección puede ser por agujeros existentes en la dovela (método discontinuo) (1), o bien por la propia cola del escudo de la tuneladora (método continuo) (2). La razón de ser principal de rellenar el trasdós es evitar desplazamientos excesivos y daños a las edificaciones en la superficie, si bien existen otras razones de aplicación, tales como: conexión entre el terreno y la estructura, prevenir movimientos excesivos de los anillos, disminuir la incidencia de malos alineamientos entre las dovelas y como barrera adicional a la infiltración del agua.

Además de atender a dichas finalidades, los morteros deben dosificarse en función de exigencias logísticas de transporte e inyección, las cuales son críticas para el desempeño de la tuneladora. Así pues, un proceso de inyección eficiente requiere morteros de relleno que puedan ser bombeados con facilidad a un caudal compatible con la velocidad de excavación, además de rellenar de manera uniforme el hueco anular $(3,4)$. Usualmente, el desarrollo de estos morteros en la práctica se basa mucho en planteamientos empíricos, fundamentado en el conocimiento previo de la empresa suministradora del producto.

En el campo más científico-técnico, el estudio de estos materiales se hace mediante modelos matemáticos que representan su comportamiento desde el punto de vista estructural y del punto de vista hidráulico (5-7). Las ecuaciones desarrolladas suelen basarse en las propiedades reológicas, las cuales juegan un papel fundamental en el comportamiento en fresco e influyen en aspectos primordiales como son la bombeabilidad y el relleno satisfactorio del hueco anular. A pesar de ello, existen pocos estudios que tratan las propiedades reológicas experimentalmente $(8,9)$, siendo los métodos generalmente utilizados para determinarlas (10-12) limitados en cuanto a su capacidad de caracterización de los morteros.

Dada la escasez de estudios experimentales y de directrices de diseño, la dosificación del mortero suele basarse en las experiencias obtenidas en obras anteriores. Las eventuales adaptaciones necesarias se realizan a través del método de prueba y error durante la ejecución del túnel. Este proceso de adaptación suele ser bastante lento y aleatorio, lo que lleva a alteraciones en la dosificación sin los resultados esperados y puede, incluso, comprometer la calidad del relleno de largos tramos.

El objetivo del presente trabajo es comparar los morteros de relleno empleados en algunos de los grandes túneles españoles más recientes. Los resultados obtenidos indican

\section{INTRODUCTION}

During the construction of tunnels with tunnel boring machines (TBM), the space left between the segmented lining and the ground is filled with the injection of a backfill mortar. Such injection may be performed either through wholes produced in the segmented lining (discontinuous method) (1) or though the TBM shield (continuous method) (2). Both procedures intend to avoid excessive displacements on the surface and the consequent structural damage of surrounding buildings. Other reasons to fill the tail void are the following: create a contact between ground and structure, prevent movement of the segmented lining, reduce the incidence of misalignments between segments and increase the watertightness of the lining.

In the continuous method, the design of the composition of the backfill mortar must consider the pumping and the injection logistics, which are critical for the performance of the TBM. An efficient injection process requires a backfill mortar that may be easily pumped at a flow rate compatible with the excavation progress besides completely filling the tail void $(3,4)$. Usually, in practice, the definition of the adequate mortar mix is based on empirical approaches.

In the scientific and technical field, the study about the material is based on mathematical models that represent the structural behaviour or the hydraulics of its transport (5-7). The equations used depend of the rheological properties that play a fundamental role in the fresh state performance, influencing the capacity of the mortar to be pumped and to fill the tail void. Despite that, there are just a few studies dedicated to the experimental characterization of the rheological properties of the material. In fact, the techniques used to assess such properties (10-12) generally present a limited characterization capability.

Due to the lack of experimental studies, the definition of the mortar composition depends on the experience obtained in previous tunnels. The required adjustments are performed through a trial and error process during construction. This process is usually quite slow and random, leading to adjustments that do not have the expected outcome and might even compromise the quality of the backfill.

In this context, the objective of the present paper is to compare the mortars applied in several recent Spanish tunnels. The results obtained indicate considerable 
diferencias significativas en cuanto a la densidad, a la consistencia y a las propiedades reológicas, lo que se traduce en diferencias de hasta un $67 \%$ en la potencia requerida del sistema de bombas de la tuneladora para inyectar el material. Asimismo se evidenció una posible correlación entre el contenido de finos y las propiedades reológicas. Esa correlación puede servir para controlar y modificar dichas propiedades de manera fácil y rápida a pie de obra.

\section{MATERIALES Y MÉTODOS}

\subsection{Ensayos propuestos}

Usualmente, la capacidad de los morteros para ser transportados y rellenar está definida por las ecuaciones que relacionan el flujo, la pérdida de carga, la diferencia de carga entre el punto inicial y el punto final y, también, por algunas propiedades del material transportado. Las principales de ellas son la tensión umbral, la viscosidad y la densidad natural en estado fresco (4).

Para caracterizar estas propiedades, en la presente campaña experimental se emplean los ensayos de densidad aparente en estado fresco (UNE 83-814-92) y de consistencia por la mesa de sacudidas (UNE 83-811-92), además del ensayo con el reómetro del tipo BML-Viscometer (realizado de acuerdo con las recomendaciones propuestas por el fabricante), poco usual en el patrimonio tecnológico de los laboratorios de caracterización estándar de morteros pero que aporta importante información. Este ensayo permite medir la tensión umbral $\left(\mathrm{T}_{0}\right)$, que marca la mínima tensión que debe ser introducida al material para que este entre en movimiento, y la viscosidad $(\mu)$, que marca el aumento de tensión requerido a fin de producir un incremento unitario en la tasa de deformación (13).

\subsection{Dosificaciones ensayadas}

En la Tabla 1 se muestran las 6 dosificaciones de mortero de relleno elegidas, que corresponden a 4 túneles construidos en España, en suelo duro (Línea 9 de Barcelona y Túnel de Pajares) y en suelo blando (Metro L3 Legazpi y M30 Túnel Sur). En la misma Tabla se observa una considerable variación en la composición de las diferentes dosificaciones fruto de diversas circunstancias de las obras. Para la campaña experimental en laboratorio, los materiales utilizados provienen directamente de las citadas obras, con lo que se busca, dentro de lo posible, repetir en laboratorio las condiciones existentes en la práctica.

Por una cuestión de uniformidad se emplea el mismo procedimiento de producción en todas ellas. Inicialmente se mezcla en seco durante 3 minutos el cemento, la ceniza volante y los áridos, añadiendo siempre primero los materiales más finos y después los más gruesos. Con la differences regarding the density, the consistency and the rheological properties. Such differences result in variations of up to $67 \%$ on the potency required of the pumping system to inject the material. Furthermore, the study shows a correlation between the fine content and the rheological properties of the backfill mortar mix. This correlation may be used to easily control and modify such properties in the worksite.

\section{EXPERIMENTAL PROGRAM}

\subsection{Tests}

The capacity of the mortar to be pumped and to fill the tail void is defined by the hydraulic equations that relate the flow rate, the pressure drop, the height difference between the initial and final points and the properties of the material (fresh state density and rheological properties) (4).

To characterize such material properties, in the present experimental program the following tests were performed: fresh state density (UNE 83-814-92), flow Table (UNE 83-811-92) and the rheology assessment with a

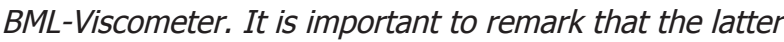
represents a differential aspect since it entails the use of an apparatus uncommon in most laboratories and rarely applied for the characterization of backfill mortars. Furthermore, this test allows the assessment of the two main rheological parameters: the yield stress (TO), which is the minimum stress applied to put in movement the material, and the viscosity $(\mu)$, defined as the increase in the tension required to produce an unitary increment of the deformation rate (13).

\subsection{Mortar mixes}

Table 1 shows the mortar mixes used in 4 Spanish tunnels built in hard ground (Línea 9 de Barcelona y Túnel de Pajares) and soft ground (Metro L3 Legazpi y M30 Túnel Sur). These mixes show a considerable differences, which may be attributed to the particularities found in each tunnel. In order to keep the conditions as close as possible from the conditions found in the worksite, the materials used in the experimental program were supplied directly from the tunnels in question.

For a matter of uniformity, the same production procedure was applied. Initially, the dry materials were mixed for 3 minutes. Then 2/3 of the water was added and mixed for 3 additional minutes. After that, the rest of the water and the admixtures were incorporated and mixed 
Tabla 1 / Table 1

Dosificaciones de los morteros de relleno.

Backfill mortar mixes.

\begin{tabular}{|c|c|c|c|c|c|c|}
\hline \multirow{2}{*}{$\begin{array}{c}\text { Materiales / } \\
\text { Materials }\left(\mathrm{kg} / \mathrm{m}^{3}\right)\end{array}$} & \multirow{2}{*}{$\begin{array}{l}\text { Línea } 9 \text { de } \\
\text { Barcelona }\end{array}$} & \multirow{2}{*}{$\begin{array}{l}\text { M30 Túnel } \\
\text { Sur }\end{array}$} & \multirow{2}{*}{$\begin{array}{l}\text { Metro L3 } \\
\text { Legazpi }\end{array}$} & \multicolumn{3}{|c|}{ Túnel de Pajares } \\
\hline & & & & $\begin{array}{l}\text { Dosificación } 1 / \\
\text { Mix } 1\end{array}$ & $\begin{array}{c}\text { Dosificación } 2 \text { I } \\
\text { Mix } 2\end{array}$ & $\begin{array}{c}\text { Dosificación } 3 \text { / } \\
\text { Mix } 3\end{array}$ \\
\hline Arena caliza / Lime sand & $(0 / 2 \mathrm{~mm}) 420$ & $(0 / 2 \mathrm{~mm}) 800$ & $(0 / 2 \mathrm{~mm}) 1500$ & $\begin{array}{c}(0 / 5 \mathrm{~mm}) \\
981\end{array}$ & $\begin{array}{c}(0 / 5 \mathrm{~mm}) \\
981\end{array}$ & $\begin{array}{c}(0 / 5 \mathrm{~mm}) \\
1049\end{array}$ \\
\hline Arena silícea / Silice sand & $(0 / 5 \mathrm{~mm}) 980$ & - & - & $\begin{array}{c}(0 / 5 \mathrm{~mm}) \\
420\end{array}$ & $\begin{array}{c}(0 / 5 \mathrm{~mm}) \\
420\end{array}$ & $\begin{array}{c}(0 / 5 \mathrm{~mm}) \\
360\end{array}$ \\
\hline Bentonita / Bentonite & - & - & 20 & - & - & - \\
\hline Filler calizo / Lime filler & 235 & - & - & - & - & - \\
\hline Ceniza volante / Fly Ash & - & 139 & 250 & 100 & 100 & 100 \\
\hline Cemento / Cement & $(\mathrm{I}-42,5 \mathrm{SR}) 250$ & $\begin{array}{c}(\mathrm{I}-42,5 \mathrm{SR}) \\
61\end{array}$ & $(\mathrm{I}-42,5 \mathrm{SR}) 55$ & (II/AV-42,5R) 50 & $\begin{array}{c}\text { (II/AV-42,5R) } \\
50\end{array}$ & $\begin{array}{c}\text { (II/AV-42,5R) } \\
50\end{array}$ \\
\hline Plastificante / Plasticizer & - & $\begin{array}{l}\text { (Plastinclair) } \\
0.9 \mathrm{~kg}\end{array}$ & $\begin{array}{c}\text { (Polyheed } \\
\text { SGE) } 2.5 \mathrm{~kg}\end{array}$ & $\begin{array}{c}\text { (Polyheed-350) } \\
6 \text { litros }\end{array}$ & $\begin{array}{c}\text { (Polyheed-350) } 6 \\
\text { litros }\end{array}$ & $\begin{array}{c}\text { (Sikament-390) } \\
1.25 \text { litro }\end{array}$ \\
\hline Estabilizante / Stabilizer & $1 \mathrm{~kg}$ & $\begin{array}{l}\text { (Preretard) } \\
0.6 \mathrm{~kg}\end{array}$ & - & $\begin{array}{c}\text { (Estabilizer-e) } \\
272 \mathrm{ml}\end{array}$ & (Estabilizer-e) $136 \mathrm{ml}$ & $\begin{array}{c}\text { (Sikatard-203) } \\
385 \mathrm{ml}\end{array}$ \\
\hline Acelerante / Accelerator & (Rebuild) 2.5 & - & - & - & - & - \\
\hline Aireante / Air entraining & - & $\begin{array}{c}\text { (Cimsil L25) } \\
0.5 \mathrm{~kg}\end{array}$ & - & $\begin{array}{c}\text { (Meycofix GA40) } \\
500 \mathrm{ml}\end{array}$ & $\begin{array}{c}\text { (Meycofix GA40) } \\
500 \mathrm{ml}\end{array}$ & $\begin{array}{c}\text { (Sikanol-M) } \\
1395 \mathrm{ml}\end{array}$ \\
\hline Agua / Water (I) & 255 & 150 & 350 & 210 & 210 & 230 \\
\hline
\end{tabular}

amasadora en funcionamiento, se adicionan 2/3 del contenido total del agua, y se amasa durante 3 minutos más. A continuación, con la amasadora en funcionamiento, se añade el resto del agua y las adiciones correspondientes, tal como recomienda el fabricante, manteniendo el amasado durante otros 6 minutos.

Finalmente, si hubiera una recomendación específica del fabricante de incorporar un componente por separado y al final del amasado, se proporciona el material correspondiente y se amasaría durante otros 3 minutos. En cualquier caso, si no hubiese dicha recomendación, la mezcla se amasaría igualmente durante esos 3 minutos. Los ensayos se realizan a partir de dos amasadas de 20 litros de mortero producidos en una amasadora mecánica de eje vertical con una capacidad nominal de 50 litros. El reparto de los materiales constituyentes que se encuentran en estado sólido y en estado líquido se hace por peso y por volumen, respectivamente.

\section{RESULTADOS}

La Tabla 2 muestra un resumen de los resultados de densidad aparente en estado fresco, de consistencia en la mesa de sacudidas y los parámetros reológicos medidos en la campaña experimental para los diferentes morteros. A continuación se presenta un análisis de esos resultados en función del tipo de ensayo.

\subsection{Densidad en estado fresco}

En un primer momento, la parte más significativa de la carga aplicada a los anillos corresponde a la presión de for 6 minutes. Finally, the admixtures that had to be incorporated separately according to the recommendations from the manufacturer were added and mixed for 3 minutes. In case, no such material was used, the mortar was mixed for 3 minutes.

The samples for the tests were obtained from mixes of 20 litres produced with a vertical axis mechanical mixer with a nominal capacity of 50 litres. It is important to remark the separation of solid and liquid materials was performed with control by weight and by volume, respectively.

\section{RESULTS}

Table 2 summarizes the fresh state density, the flow extent and rheological parameters measured for the mortars tested. The following sections present the analysis of the results obtained.

\subsection{Fresh state density}

Initially, the most important part of the load transmitted to the segmented lining is the injection pressure and the 
inyección y la presión hidrostática del mortero, la cual depende, fundamentalmente, de su densidad natural en estado fresco. Por otro lado, la densidad aparente también es esencial a la hora de evaluar la energía necesaria para el transporte e inyección del mortero. En ese contexto, un mortero con menor densidad aparente tiende a ser más adecuado, puesto que esto se refleja en una menor carga sobre la estructura del anillo $y$, al mismo tiempo, una mayor bombeabilidad $(5,14-17)$.

Dado que la densidad aparente del túnel como un todo (considerando el vacío interior) es mucho menor que la del mortero que lo envuelve, por equilibrio hidrostático surge en el túnel un empuje vertical que tiende a hacerlo flotar en el mortero. A ese fenómeno de flotación se atribuyen muchos de los problemas encontrados durante la construcción de los túneles $(5,18)$. En ese sentido, también es interesante emplear morteros con menor densidad en fresco puesto que, al ser esta más cercana a la densidad aparente del túnel como un todo, se producen fuerzas de empuje más bajas.

En la Tabla 2 se aprecia que existen dos grupos de densidades, unas más elevadas en el entorno de $2,10 \mathrm{~kg} / \mathrm{l}$ y otras menos elevadas situadas en el entorno de 1,50 $\mathrm{kg} / \mathrm{l}$, lo cual responde en gran medida, a la diferente relación agua/aglomerante usada y a la incorporación de aireantes que introduce poros en la mezcla. hydrostatic pressure of the mortar, which depends of its fresh state density. On the other hand, this property also influences the energy required to pump and inject the mortar. In this context, a mortar with smaller fresh state density tend to be easier to pump and less demanding from the structural point of view $(5,14-17)$.

Given that the overall density of the lining (considering the inner void) is much smaller than that of the surrounding backfill mortar, an uplift force appears around the tunnel. This force is responsible for many problems found during construction $(5,18)$. In this sense, the use of a mortar with smaller fresh state density is also positive, generating smaller uplift forces as it approaches the apparent density of the tunnel.

Table 2 shows that the mortar mixes may be classified in two groups in terms of fresh state densities: one around $2.10 \mathrm{~kg} / \mathrm{l}$ and the other around $1.50 \mathrm{~kg} / \mathrm{l}$. This difference is attributed to the change in the water-binder ratio and to the use of air entraining admixture that increase the void content of the material.

Tabla 2 / Table 2

Resultados de los ensayos.

Test results.

\begin{tabular}{|c|c|c|c|c|}
\hline Túnel / Tunnel & $\begin{array}{c}\text { Densidad aparente / } \\
\text { density(kg/I) }\end{array}$ & $\begin{array}{c}\text { Consistencia / } \\
\text { Flow extent }(\mathbf{m m})\end{array}$ & $\begin{array}{c}\text { Tensión umbral / } \\
\text { Yield stress }(\boldsymbol{P a})\end{array}$ & $\begin{array}{c}\text { Viscosidad / } \\
\text { Viscosity }(\boldsymbol{P a . s})\end{array}$ \\
\hline Línea 9 de Barcelona & 2.09 & 190.0 & 386.9 & 7.22 \\
\hline M30 - Túnel Sur & 2.16 & 211.5 & 254.5 & 5.12 \\
\hline Línea 3 - Legazpi & 2.06 & 170.0 & 345.5 & 3.90 \\
\hline $\begin{array}{c}\text { Pajares - Dosificación 1 } \\
\text { / Mix 1 }\end{array}$ & 1.49 & 184.0 & 246.3 & 3.42 \\
\hline $\begin{array}{c}\text { Pajares - Dosificación 2 } \\
\text { / Mix 2 }\end{array}$ & 1.49 & 185.0 & 244.9 & 5.63 \\
\hline $\begin{array}{c}\text { Pajares - Dosificación 3 } \\
\text { / Mix 3 }\end{array}$ & 2.01 & 181.5 & 270.3 & \\
\hline
\end{tabular}

La máxima presión aplicada al túnel debido al peso propio del mortero se obtiene de manera simplificada a través del producto de la densidad aparente en fresco y el diámetro del túnel. En el caso de un anillo con $9 \mathrm{~m}$ de diámetro exterior y 0,4 $\mathrm{m}$ de espesor, se verifica que la presión impuesta por las dosificaciones 1 y 2 del Túnel de Pajares son las más bajas, habiendo una reducción de aproximadamente 0,5 bar en relación a la presión impuesta por las demás dosificaciones. Tal diferencia representa una disminución en un $10 \%$ sobre la presión total media en el trasdós de anillos, la cual en diversos túneles suele estar alrededor de los 5 bares en la zona cercana al punto de inyección (4).
The product of the fresh state density and the outer diameter of the tunnel give the maximum hydrostatic pressure applied to the lining due to the self-weight of the mortar. In the hypothetical case of a tunnel with an outer diameter of $9 \mathrm{~m}$ and a thickness of $0.4 \mathrm{~m}$, the mixes 1 and 2 of Túnel de Pajares provide the smallest pressure, showing a reduction of approximately 0.5 bar in comparison with the pressure applied by the other mixes. Such difference represents a decrease of about $10 \%$ of the pressure found in several tunnels close to the injection point ( 5 bars) (4). 
Además, ello supone una reducción de aproximadamente el $35 \%$ en el empuje impuesto por el mortero de relleno al anillo.

\subsection{Consistencia medida por la mesa de sacudidas}

Al inyectarse, el mortero debe presentar características que le permitan moverse desde los puntos de inyección y ocupar todos los espacios vacíos entre el anillo y el terreno. Principalmente en los túneles con inyección discontinua, este movimiento se produce parcialmente por acción del peso propio del mortero. Dicho comportamiento es lo que se mide en el ensayo de consistencia por la mesa de sacudidas. Así pues, un mortero con mayor consistencia debería rellenar el hueco anular con más facilidad, y con una menor probabilidad de formación de rellenos parciales o de vacíos internos.

En base a los resultados de consistencia mostrados en la Tabla 2 (obtenidos en cada caso por el promedio de tres ensayos), se predice que el mortero de la M30 -Túnel Sur sea el que presente mayor capacidad de rellenar de manera satisfactoria el hueco anular, mientras que lo opuesto ocurre con el mortero de la Línea 3 - Legazpi. Dado que la relación entre la consistencia y la reología no puede simplificarse de esa manera, conviene estudiar el comportamiento reológico de los morteros teniendo en cuenta parámetros físicos como la tensión umbral de cizallamiento y la viscosidad.

\subsection{Parámetros reológicos medidos con el reómetro}

Los parámetros reológicos de caracterización más usuales son: la viscosidad y la tensión umbral de cizallamiento, obtenidos mediante un reómetro. Estos parámetros también sirven para dimensionar los sistemas de bombas, los conductos y el sistema de inyección presentes en la tuneladora $(7,19)$. Los valores de tensión umbral y viscosidad medidos con el BML-Viscometer se presentan en la citada Tabla 2. La estimación de la tensión umbral y de la viscosidad se ha realizado considerando el comportamiento reológico de un fluido de Bingham. Para ello, se ha usado el procedimiento de ensayo, las velocidades de giro y las ecuaciones de conversión descritos por Wallevik (20).

Con respecto a la tensión umbral, en dicha Tabla puede verse que el mortero de la Línea 3 - Legazpi y de la Línea 9 de Barcelona presentan el mayor valor, mientras que los morteros de la M30 - Túnel Sur y del Túnel de Pajares presentan una tensión umbral semejante entre sí, aunque algo mayor en el caso de la dosificación 3. Estos resultados reflejan que la mayor tensión umbral se obtiene en los morteros donde la cantidad de pasta es mayor (conglomerante + agua), siendo el valor máximo encontrado para el mortero de Línea 9 que incorpora $235 \mathrm{~kg} / \mathrm{m}^{3}$ de filler.
In addition, it leads to a reduction of approximately 35\% of the uplift forces applied to the lining.

\subsection{Flow extent}

During the injection in the tail void, the backfill mortar should present a fresh state behavior that allows it to move and occupy the space left between the lining and the ground. Especially in tunnels with discontinuous injection, this movement is produced partially due to the action of the self-weight of the mortar. This tendency is measured indirectly with the flow Table test. In this context, a mortar with bigger flow extent should fill better the tail void, thus reducing the incidence of partial fillings.

Based on the results shown in Table 2, the mortar of M30 - Túnel Sur should present the best capacity to fill the tail void whereas the opposite happens with the mortar of Linea 3 - Legazpi. However, given that the relation between flow extent and rheology is not completely clear, it is convenient to evaluate this problem taking into account physical parameters such as the yield stress and the viscosity of the material.

\subsection{Rheological parameters measured with the BML - Viscometer}

The yield stress and the viscosity may be used to design the injection system of the $\operatorname{TBM}(7,19)$. Table 2 presents the values measured for both parameters for the mortar mixes tested with the BML-Viscometer. The estimation of the yield stress and the viscosity was performed considering the mortar as a perfect Bingham fluid. The test procedure, the spin rates and the equations proposed by Wallevik were used (20).

The biggest yield stress was found for the mortar from the Línea 3 - Legazpi and Línea 9 de Barcelona, whereas the smallest values were obtained for the mortars from the M30 - Túnel Sur and the Túnel de Pajares. These results indicate that the bigger yield stress is more likely to happen in mixes with bigger paste (binder and water) content, with a maximum value for the case of Línea 9 de Barcelona that incorporates $235 \mathrm{~kg}$ of filler per cubic meter. 
Al tener menor tensión umbral, los morteros del Túnel de Pajares se ponen en movimiento con mayor facilidad y exigen un menor esfuerzo inicial del sistema de bombas. Estos morteros también presentan mayor capacidad de fluir por efecto de la presión empleada, con lo que rellenarían el hueco anular de manera más fácil y uniforme. Como era de esperar, los morteros de las dosificaciones 1 y 2 del Túnel de Pajares, que solo se diferencian en la cantidad de retardante, presentaron una tensión umbral prácticamente idéntica, mientras que el cambio de aditivos que hay en la dosificación 3 se reflejó en el aumento de la tensión umbral medida.

Con respecto a la viscosidad, los resultados obtenidos (Tabla 2) no muestran una concordancia con la cantidad de pasta (como en el caso de la tensión umbral) ni con la consistencia, a pesar de la existencia de diversos estudios relacionados con la estimación indirecta de las propiedades reológicas de hormigones en base a los resultados del ensayo de consistencia $(21,22)$ o del ensayo de cono modificado con la medición de parámetros adicionales que mejoran la correlación con las propiedades reológicas del hormigón (23) (En el caso de los morteros, la medición de la consistencia no se hace con el cono de Abrams, sino con la mesa de sacudidas).

El análisis conjunto de los datos de viscosidad, tensión umbral y consistencia para los 6 morteros ensayados no indica una tendencia de comportamiento clara, obteniéndose un bajo grado de correlación para todos los tipos de regresiones empleadas. Así pues, se constata que en base a los resultados de la presente campaña experimental no es posible determinar ninguna correlación entre el ensayo de consistencia en la mesa de sacudidas y los parámetros reológicos, por lo que se han buscado otro tipo de relaciones.

En lo que sigue se estudia la correlación entre tensión umbral y el contenido de finos y/o pasta, en línea con los trabajos de Logos y Nguyen (24), en los que se comprobó que la adición de una lechada con material más grueso a una lechada con material más fino lleva a la reducción de la tensión umbral y de la viscosidad. Este comportamiento es fruto de la dilución y de la frecuencia con que se observan los contactos entre partículas. Las mezclas con más finos presentan mayor probabilidad de contacto entre partículas, las cuales pasan a formar una red en el interior de la lechada y llevan a un aumento de la tensión umbral. Un estudio similar realizado por Ota y Miyamoto (25) evidencia que, en dispersiones dos tipos de partículas con diferentes dimensiones, las propiedades reológicas dependen de su dimensión.

La Figura 1 muestra los gráficos de la tensión umbral de cizallamiento y de la viscosidad en función del contenido
As expected, the mixes 1 and 2 from the Túnel de Pajares present almost the same results since they have practically the same composition. On the other hand, the change in the admixtures used in the mix 3 from the same tunnel produce an increase on the yield stress measured. Due to the smaller yield stress, mixes 1 and 2 tend to be easier to put in movement, demanding less of the pumping system. These mortars should also flow more easily providing a better fill of the tail void. The opposite would occur in the case of the mortars from Línea 3 - Legazpi and Línea 9 de Barcelona.

The viscosity results shown in Table 2 do not indicate any trend related with the amount of paste or with the flow extent. It is important to remark that several studies from the literature propose simplified formulations to indirectly estimate the rheological properties of concrete based on the results of the conventional $(21,22)$ or the modified consistency test (23) using the Abrams cone. Notice that in the case of mortars the flow extent is usually measured with the shaking table.

Despite that, the global analysis of the viscosity, the yield stress and the flow extent of the 6 mixes tested do not indicate any clear trend, giving very low degree of correlation in all comparison performed. In other words, no correlation between the flow extent and the rheological parameters may be derived based on the experimental results. Therefore, other comparisons were conducted in order to allow a simplified estimation of the rheology of the backfill mortar.

The following paragraphs present a correlation between the yield stress and the fine content in line with the study performed by Logos y Nguyen (24). The authors found that the mixture of cement grout with coarser granular material and cement grout with finer granular material led to the reduction of the yield stress and the viscosity. Such behavior may be attributed to the dilution effect and to the frequency of contact between the particles that compose the mixture. Mixes with more fines present a higher probability of contact between particles, which form a system in the grout and cause an increase of the yield stress measured. A similar study conducted by Ota $y$ Miyamoto (25) indicates that in dispersions of two types of particles with different sizes, the rheological properties of the mix depend of the particle size.

Figure 1 shows the curves that relate the viscosity or the yield stress and the fine context of each mix tested in the 


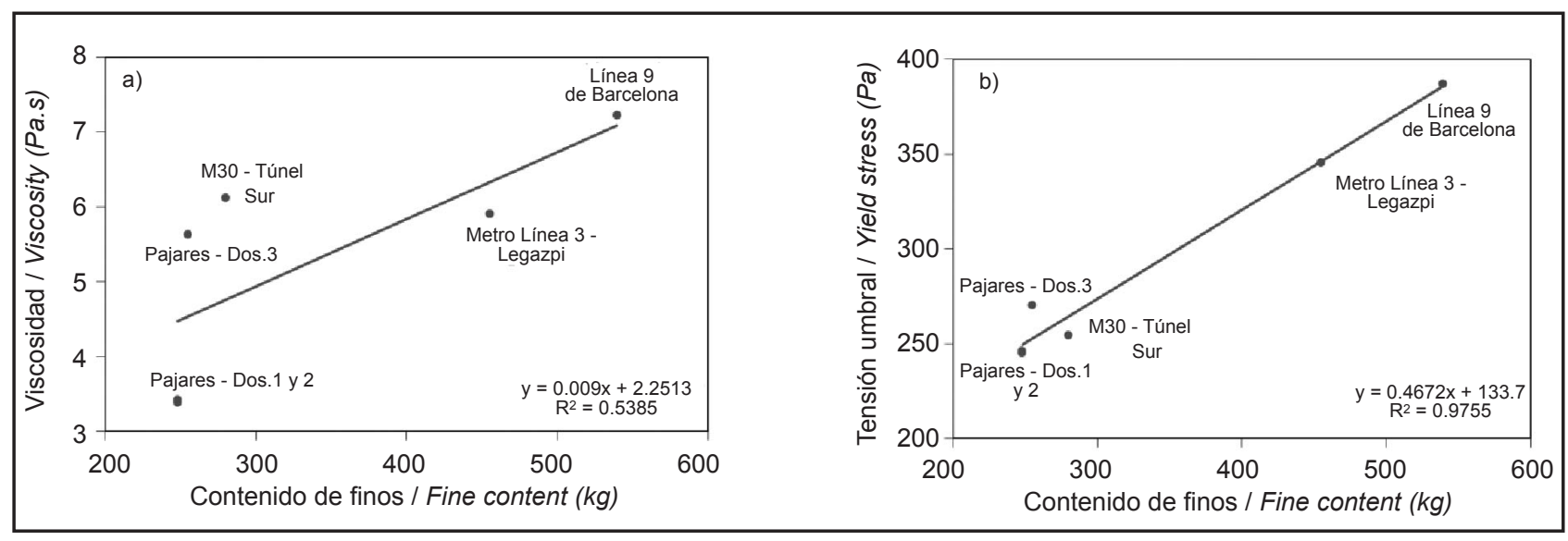

Figura 1. Correlación de la tensión umbral (a) y de la viscosidad (b) con el contenido de finos. Figure 1. Correlation between fine content and yield stress (a) or viscosity (b).

de finos de cada dosificación (se ha considerado como finos el material que pasa en el tamiz 200). Para la viscosidad el grado de correlación no es satisfactorio $\left(R^{2}=0,538\right) y$, consecuentemente, no resulta fiable para una implementación práctica. Al contrario, en el caso de la tensión umbral, el grado de correlación es elevado $\left(R^{2}=0,975\right)$, lo que hace factible una estimación simplificada de la misma a partir del contenido de finos sin necesidad de realizar ensayos complejos, con las ventajas prácticas que ello representa. De acuerdo con la regresión lineal obtenida, cada $100 \mathrm{~kg}$ de finos añadidos a la mezcla representa un aumento de 46,7 Pa en la tensión umbral de cizallamiento.

El comportamiento observado en la Figura 1 se debe probablemente a la relación entre el contenido de agua de amasado y la superficie específica de los morteros. Así, en mezclas con mayor contenido de finos el agua tiene que envolver una mayor superficie total, con lo que el espesor de la capa de agua alrededor de las partículas es más delgado. Ello aumenta la incidencia de choques y bloqueos entre partículas, dando lugar a una estructura con mayor cohesión y, por consiguiente, mayor tensión umbral. Por otra parte, en mezclas con menor contenido de finos la superficie que ha de ser envuelta es menor, con lo que la capa de agua alrededor de cada partícula alcanza mayor espesor. Debido a ello, el contacto entre partículas del esqueleto granular se reduce y hay más libertad para el movimiento relativo entre ellas. Como consecuencia se obtiene una estructura con menor cohesión y menor tensión umbral.

Cabe señalar que la propuesta de una correlación entre tensión umbral y contenido de finos aplicable a la práctica requiere la realización de una amplia campaña experimental teniendo en cuenta un gran número de variables y diversos análisis. Parece claro que dicho estudio sale del ámbito del presente trabajo, el cual se centra present experimental program. The fines were considered as the material passing the 200 sieve. The correlation obtained for the viscosity is not satisfactory $\left(R^{2}=0.538\right)$ so that the equation obtained is not adequate for a simplified estimations of this property. On the contrary, the correlation degree for the yield stress is considerably high $\left(R^{2}=0.975\right)$. In this case, the equation obtained allows the simplified estimation of the yield stress using directly the fine content, that is, without the need of performing complex tests. The linear regression of the results shows that for each $100 \mathrm{~kg}$ of fines added to the mix, there is an increase of $46.7 \mathrm{~Pa}$ in the yield stress.

The relation between the water content and the specific surface of the mortars helps to explain the behavior observed in Figure 1. In mixes with more fines, the water must cover a bigger total surface so that a thinner water layer is formed around the particles. This increases the frequency of contacts and blockage between particles, leading to more cohesion and bigger yield stress. On the other hand, mixes with fewer fines have a smaller total surface to be covered. A thicker water layer is formed around the particles thus reducing the frequency of contacts and blockages. Therefore, the material presents less cohesion and smaller yield stress.

It is important to remark that the correlation proposed for the yield stress and the fine content should be verified with a bigger experimental program taking into account other variables that may affect the results. Such study falls outside the scope of the present work, which is dedicated to the comparison of the properties and the 
fundamentalmente en la comparación de las propiedades y el comportamiento previsto para las diferentes dosificaciones reales usadas en grandes túneles españoles. En cualquier caso, a pesar de la disponibilidad de un número limitado de dosificaciones y resultados (condicionados por la cantidad de material suministrada desde cada túnel), se pone de manifiesto la existencia de una posible correlación que, si estudiada más a fondo, puede representar una herramienta bastante útil a la hora de realizar el control y la modificación de los morteros de relleno a pie de obra.

\section{CUANTIFICACIÓN DE LA BOMBEABILIDAD DE LOS MORTEROS}

Aunque los parámetros reológicos dan una idea sobre el comportamiento del mortero de relleno durante el proceso de inyección, el desempeño apreciado en la práctica también depende de las características del sistema de inyección de la tuneladora. De hecho, para cuantificar la real bombeabilidad del material (facilidad para realizar la operación de bombeo en términos de presión y energía aplicadas) hay que tener en cuenta las características del sistema compuesto por tubos y bombas, el cual es responsable por inyectar el mortero en el hueco anular.

De cara a tener una imagen más clara del desempeño esperado de cada uno de los morteros ensayados y realizar una comparación frente a condiciones de contorno uniformes, a manera de ejemplo, se estiman los parámetros de bombeo (presión y energía aplicadas por las bombas de la tuneladora) usando el mismo sistema de inyección. Para ello, se emplea el sistema de inyección de mortero de la tuneladora Guster, el cual se representa en la Figura 2. En ella se indican la longitud real (L), el diámetro $(\varnothing)$ de cada tramo y la cota altimétrica $(H)$ de los distintos puntos de inyección. Asimismo se considera que la presión que debe existir al final de cada punto de inyección es igual a la mínima que posibilitaba la colocación del mortero en el hueco anular.

El cálculo de la presión aplicada por la bomba se realiza mediante la formulación clásica de Bernoulli (26), mostrada en la ecuación [1]. Esa última permite estimar la presión que actúa al inicio de cada tramo de tubería (Pi) y, por consiguiente en la bomba, en función de la presión que actúa al final del tramo (Pf), del caudal de inyección (Q), de la pérdida de carga por unidad de longitud (f), de la longitud equivalente del tramo (Leq), de la altura inicial $(\mathrm{Hi})$, de la densidad del mortero en estado fresco $(\rho)$, de la constante gravitacional $(\mathrm{g})$, de la altura final $(\mathrm{Hf})$, del área inicial (Ai) y del área final (Af) de la tubería. estimated behavior of different mortar mixes used in Spanish tunnels. Nonetheless, despite the reduced amount of data available (conditioned by the limited amount of materials provided by each tunnel), it is obvious that the correlation might be an useful tool to perform the in situ control and the modification of mortar mixes.

\section{ASSESSMENT OF MORTAR PUMPABILITY}

Although the rheological properties provide a good image regarding the possible behaviour of the mortar during the injection process, the performance observed in reality also depends of the characteristics of the TBM injection system. In fact, to quantify the pumpability of the material (ease to perform the pumping in terms of the pressure and the potency required) it is necessary to consider the characteristics of the system composed by pipes and pumps responsible for the mortar injection in the tail void.

In order to obtain a clearer view of the performance expected in practice for each mortar tested throughout the experimental program under uniform and comparable conditions, a simplified estimation of the pumping parameters (pressure and potency applied by the pumps) was performed. For that, the injection system of the Guster TBM shown in Figure 2 was used. This Figure indicates the length $(L)$, the diameter $(\varnothing)$, the initial and the final height $(H)$ of each stretch. As a uniform criterion, it is considered that the pressure at the injection points should be the minimum required to inject the mortar in the tail void.

The pressure applied by the pump is estimated through the classic Bernoulli (26) formulation shown in equation [1]. The latter allows the calculation of the pressure acting at the beginning of each stretch (Pi) and at the pump depending of the pressure at the end of the stretch (Pf), the flow rate $(Q)$, the head loss per unit of length $(f)$, the equivalent length (Leq), the initial height $(\mathrm{Hi})$, the fresh state mortar specific weight $(\rho)$, the gravity $(g)$, the final height (Hf), the initial pipe cross section (Ai) and the final pipe cross section (Af).

$$
P_{i}=\frac{\rho \cdot Q^{2}}{2} \cdot\left(A_{f}^{2}-A_{i}^{2}\right)+\rho \cdot g \cdot\left(H_{f}-H_{i}\right)-P_{f}-f \cdot L_{e q}
$$




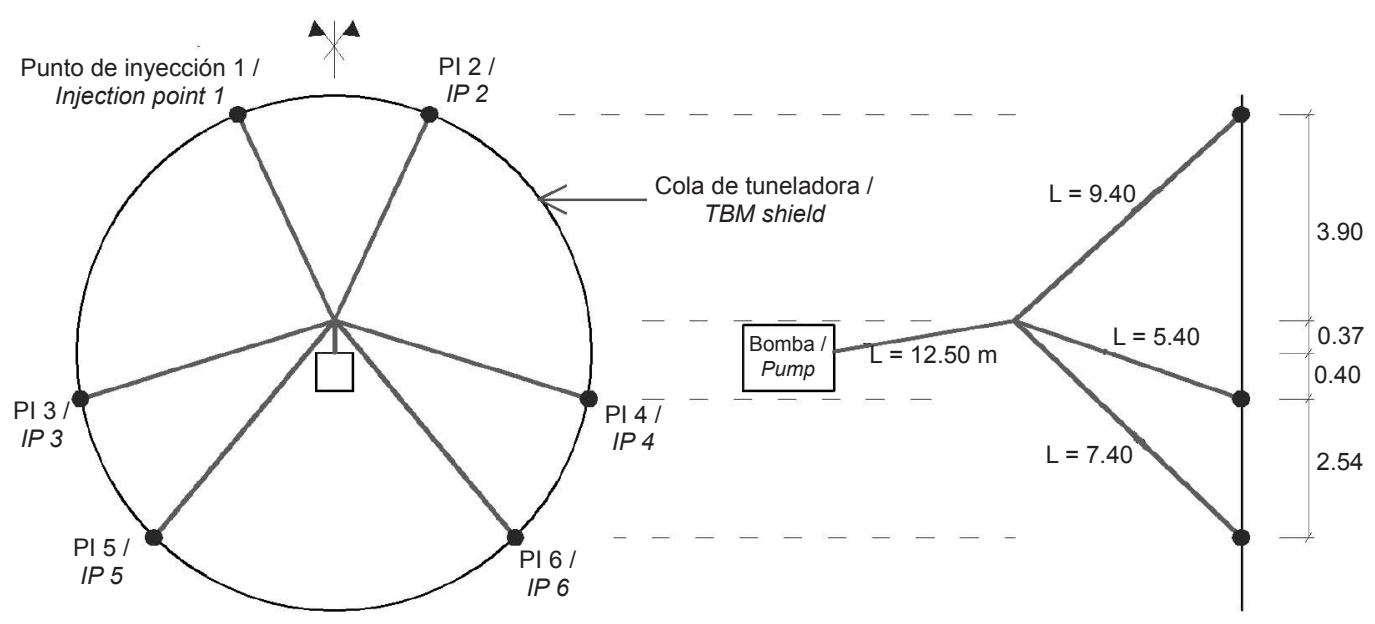

a) Vista desde la cola de la tuneladora /

b) Vista lateral / Lateral

View from the back of the TBM

Figura 2. Sistema de inyección de mortero en la tuneladora Guster. Figure 2. Injection system from the Guster TBM.

En la simulación matemática del bombeo del material se asumen algunas simplificaciones de cara a facilitar los cálculos (27). Así, se considera que a presiones inferiores a $9 \mathrm{MPa}$, la longitud equivalente del tramo (Leq) es igual a la longitud real $(L)$ del mismo $(28,29)$. Por otra parte se considera que, para un fluido de Bingham, la pérdida de carga ( $\mathrm{f}$ ) puede calcularse a través de la ecuación de Buckingham-Renier [2] a partir del caudal (Q), del radio del tubo $(R)$, de la viscosidad $(\mu)$ y de la tensión umbral (To) del material (30). Esta ecuación se aplicó con éxito al bombeo de lechadas de cemento empleadas en el proceso "Cut-and-Fill" de minas (31). Puesto que estas lechadas son usadas algunas veces con la incorporación de áridos finos, se asume que la misma ecuación también se aplica a los morteros de relleno.
Moreover, some assumptions are made to simplify the calculations (27). It is considered that for pressures beIow $9 \mathrm{MPa}$ the equivalent length (Leq) equals the real length $(L)$ of the stretch $(28,29)$. On the other hand, it is assumed that the mortar behave as a perfect Bingham fluid with a head loss ( $f$ ) estimated through the Buckingham-Renier [2] as a function of the flow rate (Q), the pipe radius $(R)$, the viscosity $(\mu)$ and the yield stress (TO) of the mortar (30). The same equation was successfully used to predict the pumping of cement paste grouts in Cut-and-Fill mines (31). Since some of these cement paste grouts sometimes include a certain addition of fine aggregates, by analogy it is considered that equation 2 also applies to backfill mortars.

$$
f=\frac{32 \cdot \pi \cdot \mu}{3 \cdot Q} \cdot\left[1-\frac{8 \cdot \tau_{0}}{3 \cdot f \cdot R}+\frac{16}{3}\left(\frac{\tau_{0}}{f \cdot R}\right)^{4}\right]
$$

El cálculo de la presión exigida del sistema de bombas se realiza en las ecuaciones [1] y [2] para diferentes caudales de inyección usando los valores de las propiedades reológicas y de densidad aparente indicados en la Tabla 2. Los resultados obtenidos para los morteros estudiados se muestran en la Figura 3a. En ella se observa que el aumento caudal de inyección se logra mediante el aumento en la presión de la bomba. Tal como se esperaba, los morteros de las dosificaciones 1 y 2 del Túnel de Pajares son los que necesitan menor presión para ser bombeados. Por ende, estos morteros también son los que menos solicitan el conjunto de bombas al requerir una presión entre 3,07 bares - para un caudal de inyección 0,35 m³/horay 4,37 bares - para a un caudal de $17,47 \mathrm{~m}^{3} /$ hora-.
The minimum pressure required to pump the mortar is obtained by applying the data measured in the experimental program in equations [1] and [2]. The results for different flow rates are presented in Figure 3a. The latter indicates that the increase of the flow rate implies an increase in the pressure generated by the pump. As expected, the mortar mixes 1 and 2 from Túnel de Pajares require the smallest pressure to be pumped. Consequently, these mortars demand less from the pump system that applies 3.07 bars for a $0.35 \mathrm{~m}^{3} /$ hour flow rate and 4.37 bars for a $14.47 \mathrm{~m}^{3} /$ hour flow rate. 
En cambio, las presiones mínimas exigidas al conjunto de bombas para el bombeo del mortero de la Línea 9 de Barcelona son considerablemente mayores, con una variación de entre 4,77 —para el caudal más bajo- y 7,24 bares —para el caudal más elevado-.

En la Figura $3 \mathrm{~b}$ se muestra la potencia requerida del sistema de bombas para inyectar los morteros de relleno en el hueco anular, la cual se obtiene al multiplicar la presión introducida por la bomba y el caudal de inyección resultante. Tal y como se puede apreciar, la potencia requerida para el bombeo de los morteros aumenta de manera aproximadamente lineal con el aumento del caudal de inyección. Así, para el caudal máximo considerado, el mortero de la Línea 9 de Barcelona requiere una potencia un $67 \%$ mayor que la exigida en el bombeo de los morteros de las dosificaciones 1 y 2 de Pajares. Esas observaciones son consistentes con los resultados de las auscultaciones realizadas en las obras reales. Así pues, en la Línea 9 de Barcelona se han verificado serios problemas de bombeo con presiones muy elevadas y atascos, mientras que en el Túnel de Pajares los problemas en el bombeo y las presiones apreciadas son mucho menores. Es evidente que tales constataciones, en parte, también se deben a las diferencias en las demás condiciones de contorno encontradas en las dos obras (4).
The pumping of the mix from Línea 9 de Barcelona demands a pressures equal to 4.77 bars and 7.24 bars for the same flow rates, respectively.

Figure $3 b$ shows the potency necessary to inject the backfill mortar in the tail void, obtained by multiplying the pressure applied by the pumps and the flow rate. Notice that the potency increases almost linearly with the increase of the flow. For instance, the mortar mix from Línea 9 de Barcelona requires $67 \%$ more potency than the required by the mixes 1 and 2 from Túnel de Pajares. Such outcome is consistent with the result of real case inspections since the latter showed several pumping problems (high pressures and blockages) during construction, whereas the latter presented smaller pressures and problems. Notice that, in part, this dissimilarity may be due to differences in the surrounding conditions found in each work site (4).
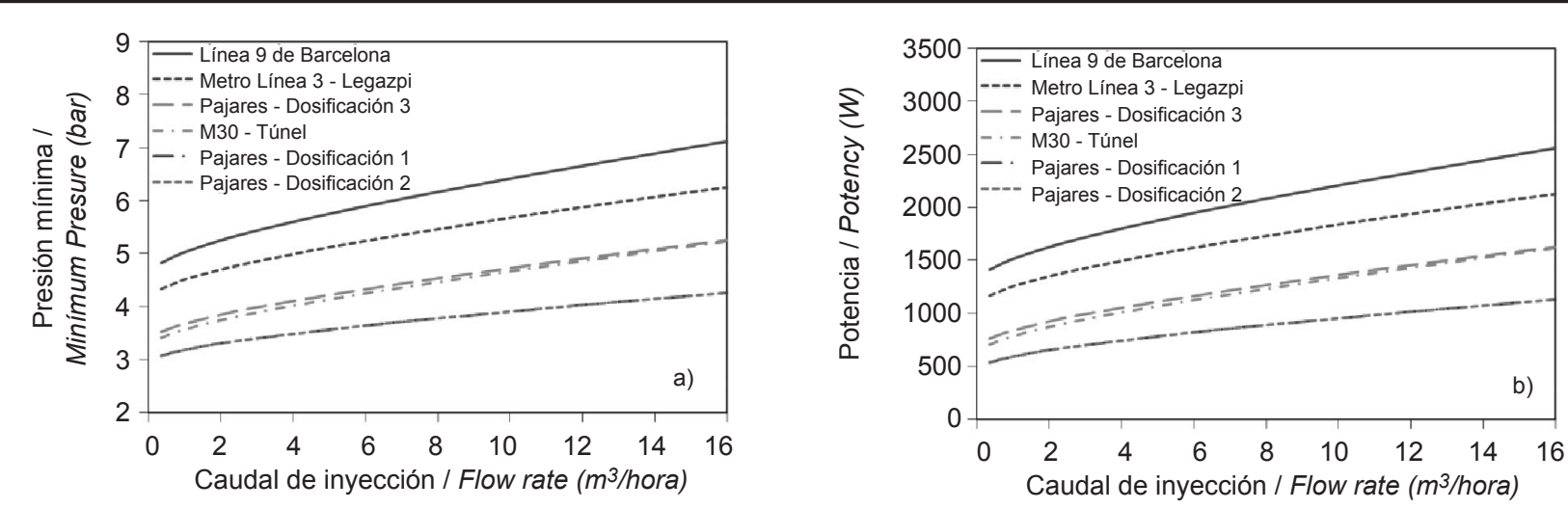

Figura 3. Presión mínima (a) y Potencia mínima (b) requerida para bombeo e inyección del mortero. Figure 3. Minimum pressure (a) and minimum potency (b) required to pump and inject the mortar.

\section{CONCLUSIONES}

En el presente estudio se han encontrado diferencias significativas en las propiedades de los morteros empleados en España. La ausencia de una justificación clara para la disparidad de resultados encontrada refleja la necesidad de profundizar en el estudio de esos materiales, así como de evaluar las repercusiones de las diferentes propiedades en la eficiencia y en la calidad del proceso constructivo. A continuación se presentan las principales conclusiones derivadas de ese estudio.

\section{CONCLUSIONS}

This study shows important differences between the properties of backfill mortars used in Spanish tunnels. The absence of a clear justification for such disparity of results indicates the necessity to deepen the research about the backfill mortar as well as to evaluate the impact of the variations in their properties over the efficiency and the quality of the construction process. The following conclusions may be derived from the present study. 
- Las variaciones tanto en la densidad como en las propiedades reológicas tienen una clara repercusión en el desempeño de los morteros de relleno durante las etapas de bombeo, inyección y relleno del hueco anular. En ese contexto, un aumento de la densidad o de la tensión umbral del mortero conduce a un consecuente aumente la presión y la potencia requerida del sistema de bombas de la tuneladora, incrementando así el riego de problemas durante ejecución del relleno.

- La cuantificación simplificada de la bombeabilidad indica que el mortero de la Línea 9 de Barcelona es el de más difícil bombeabilidad y, a priori, el de menor capacidad para rellenar uniformemente el hueco anular. De acuerdo con las estimaciones realizadas, este requiere del sistema de bombas una potencia un $67 \%$ mayor que la exigida en la inyección de los morteros de las dosificaciones 1 y 2 de Pajares.

- El ensayo con el reómetro representa un valor añadido importante para la caracterización de los morteros de relleno dado que permite la identificación de diferencias en el comportamiento en estado fresco que no son detectadas en otros ensayos de trabajabilidad. Ello resulta evidente al comparar la dosificación 1 del Túnel de Pajares y de la Línea 9 de Barcelona que presentan una extensión de flujo en la mesa de sacudidas igual a 184 y $190 \mathrm{~mm}$, respectivamente. A pesar de la aparente mayor fluidez, esta última tiende a ser menos bombeable, ya que presenta una tensión umbral un $57 \%$ mayor y una viscosidad $114 \%$ mayor que las medidas en la dosificación 1 del Túnel de Pajares.

- Aunque se dispone de un número de datos reducido (condicionado por la limitada cantidad de material suministrada desde cada túnel), un análisis preliminar sugiere que en los morteros de relleno hay una correlación entre el contenido de finos presentes en la mezcla y la tensión umbral de la misma. En ese sentido, un aumento de la cantidad de finos produce un aumento de la tensión umbral. Asimismo, se debe realizar una campaña experimental más amplia con el fin de evaluar la influencia de los diferentes parámetros de la dosificación (relación agua/aglomerante, contenidos de aditivos, entre otros) en el comportamiento medido.

En vista de los resultados obtenidos y de cara a facilitar el proceso de bombeo, inyección y relleno satisfactorio del hueco anular, se recomienda el uso de morteros con valores bajos de densidad en estado fresco, lo que se puede lograr mediante la incorporación de aditivos aireantes. Por otro lado, se deben usar morteros con tensiones umbrales bajas (inferiores a los $300 \mathrm{~Pa}$ ) reduciendo el contenido de finos que pasan por el tamiz 200. Este contenido debe estar por debajo de los $350 \mathrm{~kg} / \mathrm{m}^{3}$ de acuerdo con la correlación estimada en el apartado 3.3. La observación de estas recomendaciones
- Variations in the fresh state density and in the rheological properties affect the performance of the backfill mortar during the pumping, injection and fill of the tail void. In this context, an increase of the density, of the yield stress or of the viscosity of the mortar leads to a consequent increase both in the pressure and the potency required from the pumping system of the TBM. This intensifies the risk of problems during construction.

- The quantification of the pumpability indicates that the backfill mortar from Línea 9 de Barcelona is the most difficult to pump and the more likely to produce filling problems of the tail void. Based on the estimations performed, this mortar needs $67 \%$ more potency than the required to pump the mixes 1 and 2 from Túnel de Pajares.

- The test with the rheometer shows an important benefit in terms of the capacity to characterize the properties of the backfill mortar, allowing the identification of differences not detected with classic workability tests. For example, notice that the mix 1 from Túnel de Pajares and the mix from Línea 9 de Barcelona present similar flow extents (184 and $190 \mathrm{~mm}$, respectively). However, in spite of the apparent higher fluidity, the mix from Línea 9 of Barcelona tend to be the hardest to pump since it presents an yield stress 57\% higher and a viscosity $114 \%$ higher than the measured for mix 1 of Túnel de Pajares.

- Although the amount of data available is limited (due to restriction regarding the material sent from each tunnel), a preliminary analysis suggests that there is a correlation between the yield stress and the fine content of the backfill mortar mixes. In this sense, the yield stress increases as the fine content increases. It is important to extend the experimental campaign in order to validate the correlation obtained in this study and to take into account the influence of other parameters such as the water/cement ratio, the type and amount of admixtures, among others.

The results obtained indicate that backfill mortars with low fresh state specific weight should be used in order to avoid problems during the pumping, injection and filling of tail void. For that, it is advisable to incorporate air entraining admixtures. On the other hand, the design should favour the application of backfill mortars with low yield stress (below $300 \mathrm{~Pa}$ ), which is achieved by reducing the fine content of mixes that passes the 200 sieve. This fine content should be smaller than $350 \mathrm{~kg} / \mathrm{m}^{3} \mathrm{ac}$ cording with the correlation derived in section 3.3. These recommendations may contribute for the design of new 
puede contribuir tanto al diseño de nuevas mezclas más conformes con el sistema de inyección de cada túnel, como a la corrección de eventuales incompatibilidades observadas a lo largo del proceso constructivo.

\section{AGRADECIMIENTOS}

El primer autor agradece al Ministerio de Educación y Ciencia de España por la beca FPI ligada al proyecto BES2006-13592. Asimismo agradece a Fomento de Construcciones y Contratas, S. A., la confianza depositada a lo largo de los años, en la realización de diferentes proyectos de investigación y, en especial en el proyecto en el que se integra el presenta trabajo (Proyecto HATCONS). Todo ello ha sido fruto del empuje decidido de Enrique Bofill y Francisco Capilla, a los que se les quiere agradecer la oportunidad de estudiar estos temas. backfill mortar mixes compatible with the injection system found in each tunnel and for the in situ correction of incompatibilities observed during the construction process.

\section{ACKNOWLEDGEMENTS}

The first author thanks the Ministerio de Educación y Ciencia de España for the FPI scholarship linked with the project BES-2006-13592. The authors thank Fomento de Construcciones $y$ Contratas, $S$. $A$, for the confidence deposited throughout the years in several research projects, especially the one included in the present study (HATCONS). This work is the result of the constant support of Enrique Bofil and Francisco Capilla, who have provided the opportunity to study this subject.

\section{BIBLIOGRAFÍA / BIBLIOGRPHY}

(1) Széchy, K.: The art of tunnelling, p. 891, Budapest: Akadémiai Kiadó (1970).

(2) Varios Autores: Ingeo de túneles, Serie: Ingeniería de Túneles, Libro 1, Madrid, España : Entorno Grafico, ISBN 84-921708-5-9 (1999).

(3) EFNARC: Specification and guidelines for the use of specialist products for soft ground tunnelling, European Federation of Producers and Contractors of Specialist Products for Structures (2005).

(4) Cavalaro, S. H. P.: Evaluación de aspectos tecnológicos en túneles construidos con tuneladora y dovelas prefabricadas de hormigón, Tesis Doctoral, p. 320, E.T.S. Ingenieros de Caminos, Canales y Puertos. UPC, Barcelona, Spain (2009).

(5) Blom, C. B. M.: Design philosophy of concrete linings for tunnels in soft soils, p. 184, Delft, The Netherlands: Delft University Press (2002).

(6) Ding, W. Q.; Yue, Z. Q.; Tham, L. G.; Zhu, H. H.; Lee, C. F.; Hashimoto, T.: "Analysis of shield tunnel", John Wiley and Sons Ltd. International Journal for Numerical and Analytical Methods in Geomechanics (2004), vol. 28, no 1, pp. 59.

(7) Bezuijen, A.; Talmon, A.: "Grout properties and their influence on backfill grouting", Proceedings of the 5th International Symposium on Geotechnical Aspects of Underground Construction in Soft Ground, p. 187, Amsterdam (2005).

(8) Bertomeu, J.: Libro de ruta para un ingeniero de turno de una tuneladora EPB, TFC presentado a la ETSICCPB, Barcelona (2010).

(9) López, M. R.: Desarrollo de un dispositivo para la determinación de la aptitud del hormigón para el bombeo, TFC presentado a la ETSICCPB (2011).

(10) Bezuijen, A.; Talmon, A. M.: "Grout, the foundation of a bored tunnel", Thomas Telford Services Ltd, BGA International Conference on Foundations, Innovations, Observations, Design and Practice, p. 129, Dundee, United Kingdom (2003).

(11) Talmon, A. M.; Aanen, L.; van der Zon, W. H.: "Stromingsgedrag groutinjectie Delft Cluster", Delft Cluster, External research report (2002).

(12) Talmon, A. M.; Bezuijen, A.: "Grouting the tail void of bored tunnels: the role of hardening and consolidation of grouts", 5th International Symposium Geotechnical Aspects of Underground Construction in Soft Ground, Amsterdam, The Netherlands, 15-17 de junio de 2005. ISSMGE-TC28 (2005).

(13) Wallevik, J. E.: Rheology of particle suspensions, Doctoral Thesis, Trondheim, Norway: The Norwegian University of Science and Technology (NTNU) (2003).

(14) Blom, C. B. M.; Lokhorst, S. J.; A., Slenders B. M.; A., Kwast E.: Influences of physical grout flow around bored tunnels, Geotechnical Aspects of Underground Construction in Soft Ground, p. 253, London, England: Taylor \& Francis Group (2006). (15) Bezuijen, A.; Talmon, A. M.: "Grout pressure measurements during tunnelling", ITA Conference. Amsterdam: s.n. (2003).

(16) Bezuijen, A.; Talmon, A. M.: "Grout pressures around a tunnel lining. Influence of grout consolidation and loading on lining", Tunnelling and Underground Space Technology, vol. 19, 4-5 (2004), pp. 443.

(17) Bezuijen, A.; Talmon, A. M.; Kaalberg, F. J.; Plugge, R.: "Field measurements of grout pressures during tunnelling of the Sophia Rail Tunnel", Soils and Foundations, vol. 44, no 1 (2004), pp. 39.

(18) Cavalaro, S. H. P.; Blom, C. B. M.; Walraven, J. C.; Aguado, A.: "Structural analysis of contact deficiencies in segmented lining", Tunnelling and Underground Space Technology (2011), doi: 10.1016/j.tust.2011.05.004. 
(19) Debrauwer, R.: "Groutbelasting op een tunnellining", Eindrapport, Delft: TU Delft (2002).

(20) Wallevik, J. E: Rheology of Particle Suspensions - Fresh Concrete, Mortar and Cement Paste with Various Types of Lignosulfonates, Ph.D. thesis, Department of Structural Engineering, The Norwegian University of Science and Technology, ISBN 82-471-5566-4, ISSN 0809-103X, pp. 401 (2003).

(21) Schowalter, W. R.; Christensen, G.: "Toward a rationalization of the slump test for fresh concrete: comparisons of calculations and experiments", Journal of Rheology, vol. 42, no 4 (1998), pp. 865.

(22) Shi, Y-X.; Matsui, I.; Guo, Y-J.: "A study on the effect of fine mineral powders with distinct vitreous contents on the fluidity and rheological properties of concrete", Cem. and Concr. Res., vol. 34, no 8 (2004), pp. 1381.

(23) Ferraris, C. F.; De Larrard, F.: "Modified Slump Test to Measure Rheological Parameters of Fresh Concrete", Cem., Concr. and Aggr., vol. 20, no 2 (1998), pp. 241.

(24) Logos, C.; Nguyen, Q. D.: "Effect of particle size on the flow properties of a South Australian coal-water slurry", Powder Technology, vol. 88, no 1 (1996), pp. 55.

(25) Ota, M.; Miyamoto, T.: "Optimum particle size distribution of an electrorheological fluid", Journal of Applied Physics, vol. 76, no 9 (1994), pp. 5528.

(26) White, F. M.: "Avoidance of blockages in concrete pumping process", ACI Materials Journal, vol. 102, 3 (2005), 183 p. (27) Río, O.; Rodríguez, A.; Nabulsi, S.; Álvarez, M.: "Pumping Quality Control Method Based on Online Concrete Pumpability Assessment", ACI Materials Journal, vol. 108, 4 (2011), pp. 423.

(28) Kaplan, D.; De Larrard, F.; Sedran, T.: Fluid Mechanics, Mcgraw-Hill Series in Mechanical Engineering, Edición 7 (2010), pp. 896.

(29) Kaplan, D.; de Larrard, F.; Sedran, T.: "Design of concrete pumping circuit", ACI Materials Journal, vol. 102, no 2 (2005), pp. 110.

(30) Geankoplis, C. J.: "Principles of momentum transfer and applications", Transport process and unit operations (1995), pp. 114.

(31) Belem, T.; Benzaazoua, M.: "An overview of the use of paste backfill technology as a ground support method in cut-and-fill mines", In: 5th International Symposium on ground support in mining and underground construction, Perth, Western Australia, Australia: s.n., 28-30 de September de 2004 (2004), pp. 637. 